\title{
The Squash Bug, Anasa Tristis (Heteroptera: Coreidae): A Potential Greenhouse Pest of Beit Alpha Cucumber 1
}

Silvia I. Rondon, Daniel J. Cantliffe and James F. Price ${ }^{2}$

The Beit alpha cucumber, Cucumis sativus L., a crop grown under protective structures in the Middle East, Europe and Mexico, is a relatively new greenhouse commodity in Florida that is competing in the marketplace with the traditional Dutch-type cucumber as well as field-grown cucumbers. While the Beit alpha cucumber produces a seedless fruit with a thin, smooth skin like the Dutch type (Fig. 1), productivity can be much higher than other cucumber types (Shaw et al., 2001). The Beit alpha cucumber can be grown successfully year-round in greenhouses, but pests must be controlled for optimal production.

The squash bug, Anasa tristis (DeGeer) (Heteroptera: Coreidae), is considered an important pest of cucurbits in open fields in the U.S. (Bonjour and Fargo, 1989; Cook and Neal, 1999). In the greenhouse, the squash bug can infest Beit alpha cucumber causing considerable damage (Rondon et al., 2003) (Fig. 2).

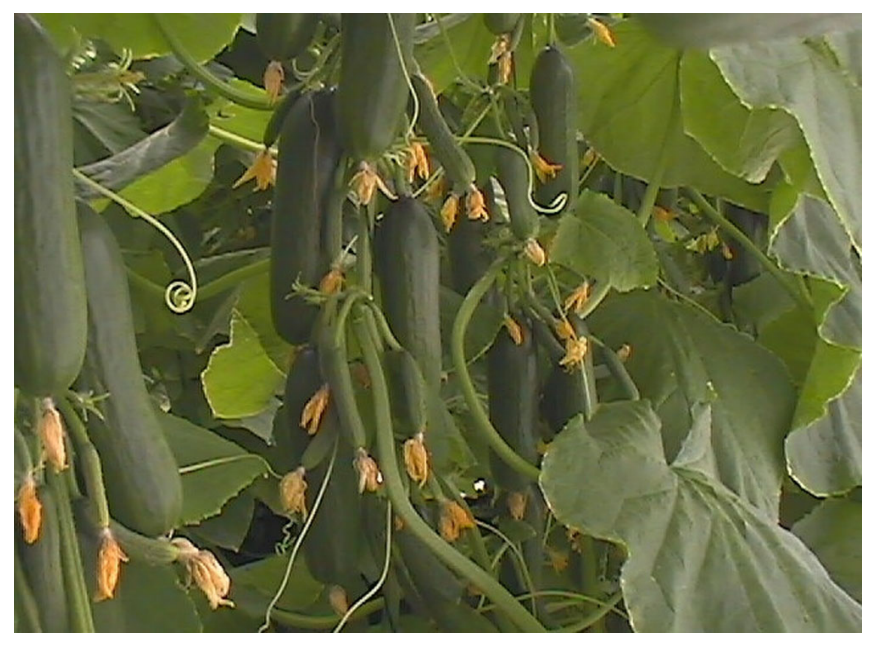

Figure 1. Beit alpha cucumbers grown in a greenhouse. Credits: N.L. Shaw, UF/IFAS, Horticultural Sciences Department

1989); and Beit alpha cucumber in the greenhouse, (Rondon et al., 2003).

\section{Distribution and Biology of the Squash Bug in the Beit Alpha Crop}

\section{Hosts}

Hosts of the squash bug include squash, pumpkin, cucumber, melon (Bonjour and Fargo,
Egg masses in the greenhouse indicate the presence of female squash bugs and subsequent nymphs. Most egg masses $(11 \pm 1.6)$ are layed in the

1. This document is HS992, one of a series of the Horticultural Sciences Department, Florida Cooperative Extension Service, Institute of Food and Agricultural Sciences, University of Florida. Publication date: October 2004. Please visit the EDIS Web site at http://edis.ifas.ufl.edu.

2. Silvia I. Rondon, adjunct research associate, Daniel J. Cantliffe, professor and chair, Horticultural Sciences Department; James F. Price, associate professor, GCREC-Bradenton, Cooperative Extension Service, Institute of Food and Agricultural Sciences, University of Florida, Gainesville, 32611.

The Institute of Food and Agricultural Sciences (IFAS) is an Equal Employment Opportunity - Affirmative Action Employer authorized to provide research, educational information and other services only to individuals and institutions that function without regard to race, creed, color, religion, age, disability, sex, sexual orientation, marital status, national origin, political opinions or affiliations. For information on obtaining other extension publications, contact your county Cooperative Extension Service office. Florida Cooperative Extension Service/Institute of Food and Agricultural Sciences / University of Florida / Larry R. Arrington, Interim Dean 


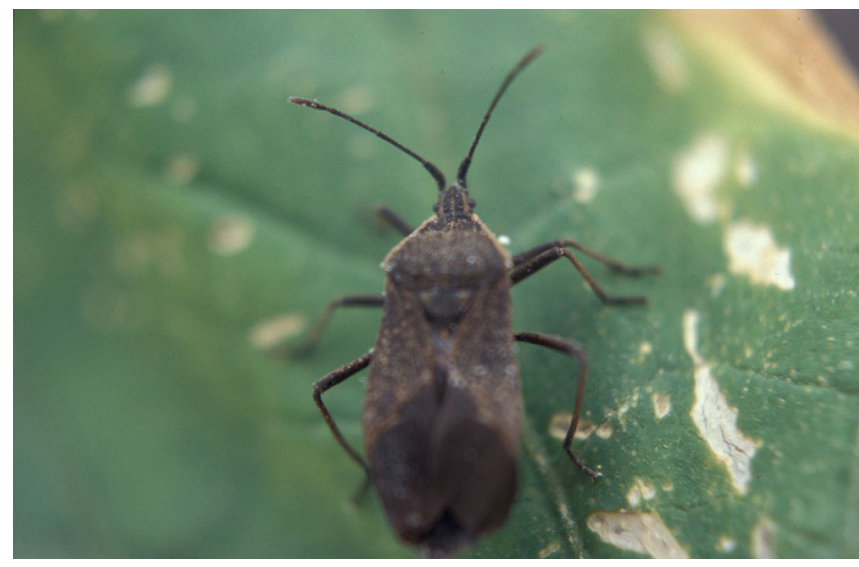

Figure 2. The squash bug, Anasa tristis (DeGeer), on Beit alpha cucumber. Credits: S.I. Rondon, UF/IFAS, Horticultural Sciences Department

upper level of the crop, since it is frequented by the adults, followed by the middle third $(6 \pm 1.2)$ and in the lower third $(3 \pm 0.8)$. Average number of eggs laid per mass is $20 \pm 3.3$. Egg masses are roughly circular (Fig. 3).

The mean developmental times for egg, $1^{\text {st }}$ instar, and $2^{\text {nd }}$ instar are $6.7 \pm 1.8,5.0 \pm 1.2$, and $3.2 \pm 1.0$ days, respectively (Fig. 4) (Rondon et al., 2003).

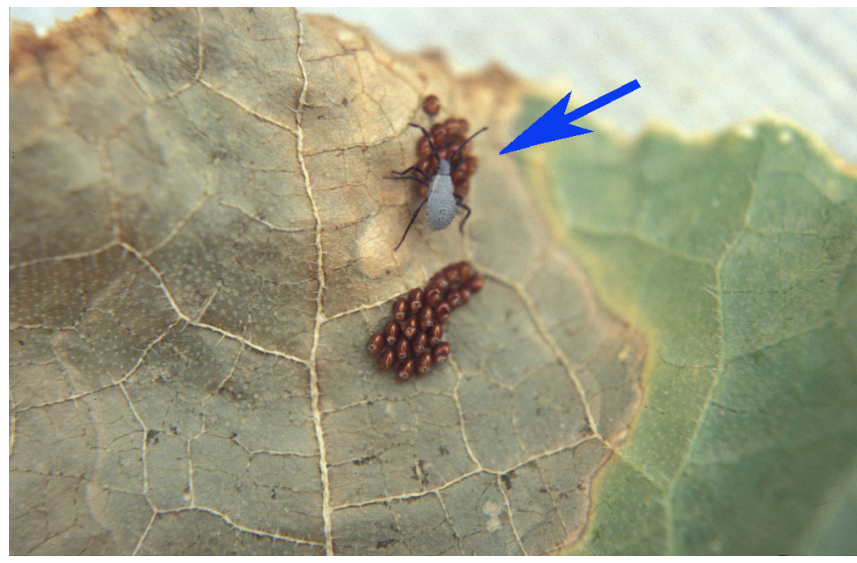

Figure 3. Egg masses of squash bug. Also, one $1^{\text {st }}$ instar individual. Credits: E. Jovicich, UF/IFAS, Horticultural Sciences Department

\section{Control Methods}

No single pest management tactic (chemical, cultural, or biological control; or host plant resistance) has been entirely effective in controlling squash bugs (Zavala, 1991; Olson et al., 1996). Early detection of squash bugs in the greenhouse is imperative because moderate infestations can cause plant wilt in cucumber (Fig. 5). Important natural

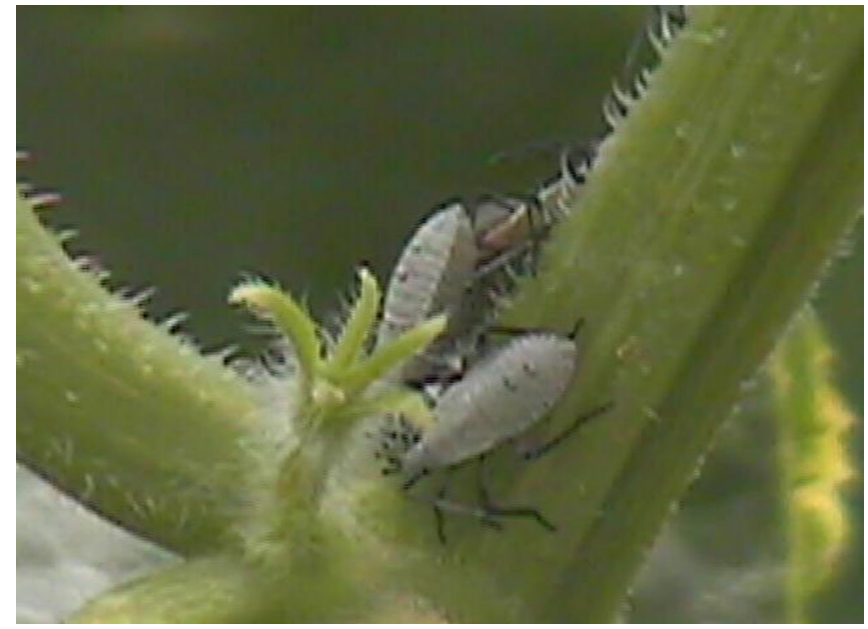

Figure 4. Nymphs $2^{\text {nd }}$ instar of the squash bug in a Beit alpha cucumber auxiliary node. Credits: E. Jovicich, UF/IFAS, Horticultural Sciences Department

enemies of the squash bug are the parasitic tachinid fly, Trichopoda pennipes (Fab.) (Fig. 6), and scelionid, Eumicrosoma spp. wasp (Van Driesch and Bellows, 1996). Both species occur in nature and are not commercially available. Preliminary studies have shown that the pink spotted lady beetle, Coleomegilla maculata (DeGeer) (Fig. 7) can control effectively first instars of the squash bug if released earlier in the season (Rondon et al., 2003).

Squash bug adults are difficult to kill with insecticides. It is advisable to target nymphs since they are more susceptible (Capinera, 2003). For chemical control options, visit the UF/IFAS Extension Web site at http://edis.ifas.ufl.edu.

\section{Literature Cited}

Bonjour, E.L., and W.S. Fargo. 1989. Host Effects on the Survival and Development of Anasa tristis (Heteroptera: Coreidae). Environ. Entomol. 18:1083 - 1085.

Capinera, J.L. 2003. Squash Bug, Anasa tristis (DeGeer) (Heteroptera: Coreidae). UF/IFAS, Fla. Coop.Ext. Serv., EENY-077.

Cook, C.A., and J.J. Neal. 1999. Feeding Behavior of Larvae of Anasa tristis (Heteroptera: Coreidae) on Pumpkin and Cucumber. Environ. Entomol. 28:173-177.

Olson, D.L., J.R. Nechols, and B.W. Schurle. 1996. Comparative Evaluation of Population Effect 


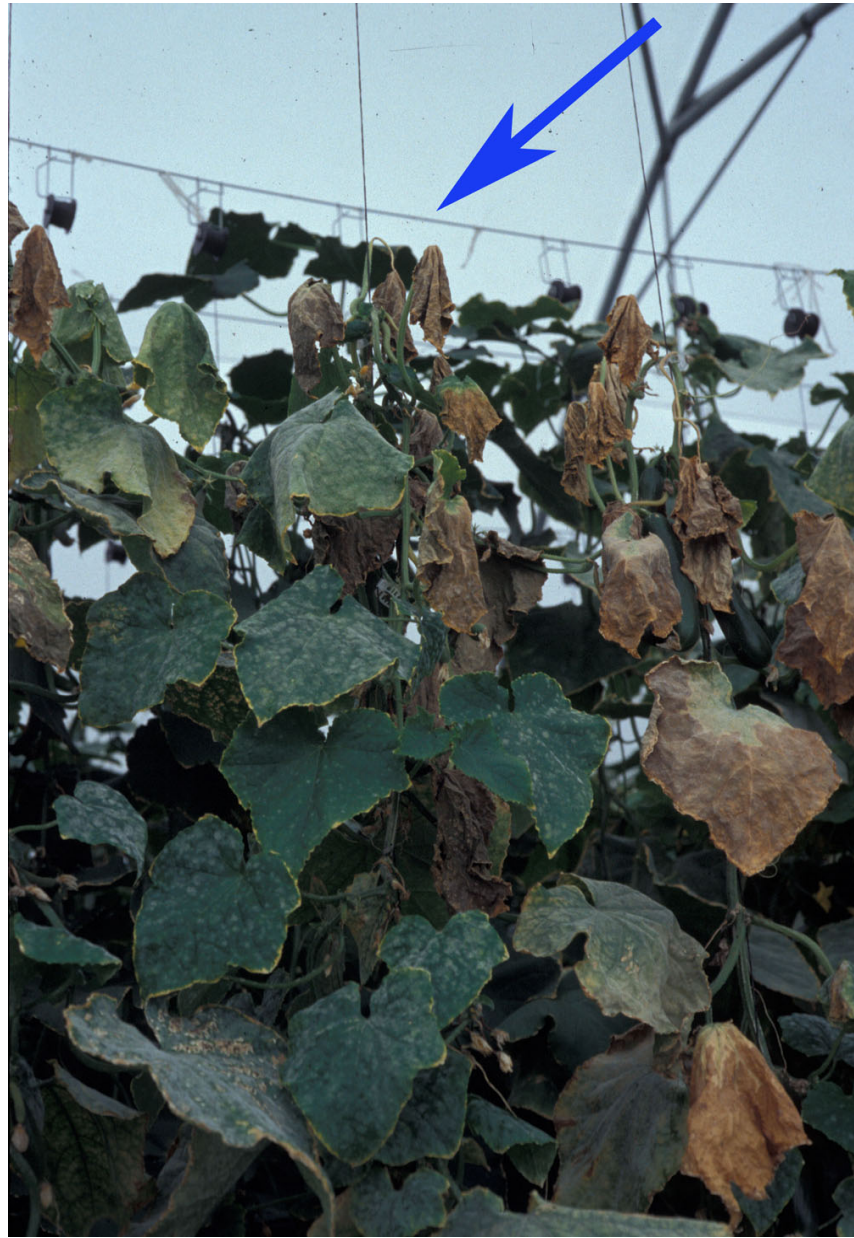

Figure 5. Damage caused by the squash bug in Beit alpha cucumber. Credits: Credits: S.I. Rondon, UF/IFAS

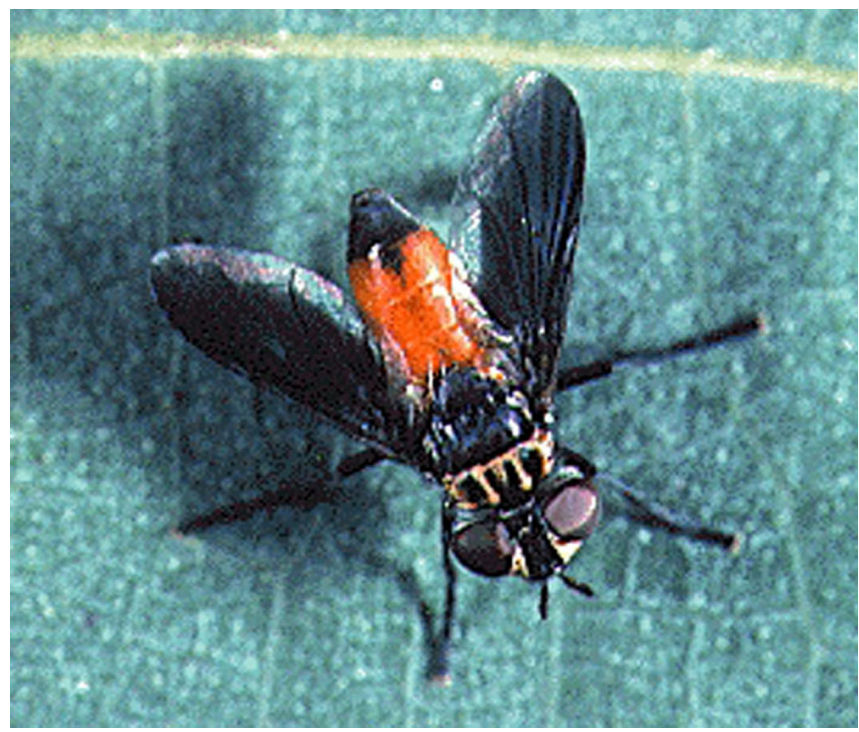

Figure 6. Trichopoda pennipes, parasitoid of the squash bug. Credits: J.K. Clark, Cornell University

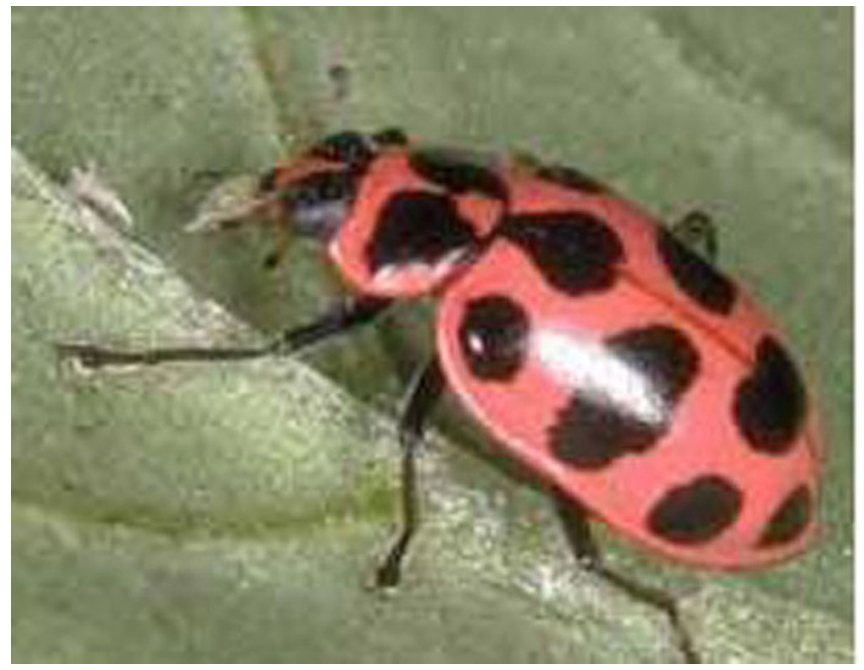

Figure 7. The pink spotted lady beetle. Credits: Marlin Rice, lowa State University

and Economic Potential of Biological Suppresion Tactics Versus Chemical Control for Squash Bugs (Heteroptera: Coreidae) Management on Pumpkins. J. Econ. Entomol. 89:631-639.

Rondon, S.I., D.J. Cantliffe, and J.F. Price. 2003. Anasa tristis (Heteroptera: Coreidae) Development, Survival, and Egg Distribution on Beit Alpha Cucumber and as a Prey for Coleomegilla maculata (Coleoptera: Coccinellidae) and Geocoris punctipes (Heteroptera: Lygaeidae). Fla. Entomol. 86:488-490.

Shaw, N.L., D.J. Cantliffe, and S.B.Taylor. 2001. Hydroponically Produced Galia Muskmelon: What's the Secret? Proc. Fla. State Hort. Soc. 114:288-293.

Van Driesche, R.G., and T.S. Bellows, Jr. 1996. Biology and Arthropod Parasitoids and Predators, pp. 309-335. In R. G. Van Driesche and T. S. Bellows, Jr. (eds.), Biological Control. Chapman and Hall, NY.

Zavala, M.S. 1991. Relative Toxicity of Selected Pesticides to the Squash Bug, Anasa tristis (DeGeer) (Hemiptera: Coreidae) and Its Egg Parasitoid, Gryon pennsylvanicum (Hymenoptera: Scelionidae). M.S. Thesis, Kansas State University, Manhattan, KS.

\section{Additional Information}

\section{Related Web sites:}

Insect Management for Cucurbits (Cucumber, Squash, Cantaloupe, and Watermelon), UF/IFAS, 
Fla. Coop. Ext. Serv., ENY-460.

http://edis.ifas.ufl.edu/IN168

Squash Bug, Anasa tristis (DeGeer) (Insecta:

Hemiptera: Coreidae), UF/IFAS, Fla. Coop. Ext.

Serv., ENY-460. http://edis.ifas.ufl.edu/IN234

Vegetable Insect Identification and Management

- Florida Greenhouse Vegetable Production

Handbook, Volume 3, UF/IFAS, Fla. Coop. Ext.

Serv., HS798. http://edis.ifas.ufl.edu/CV274

Protected Agriculture Greenhouse and the Florida/Israeli Protected Agriculture Project, http://hos.ufl.edu/protectedag/ 